Banco, Volume 1, November 2019

\title{
ANALISIS ETIKA BISNIS ISLAM TERHADAP PERILAKU PENADAH IKAN EKSPOR DI KEC. MALLUSETASI KABUPATEN BARRU
}

\author{
Al Maidah Nur \\ IAIN Parepare \\ almaidahnur21@iainparepare.ac.id \\ Muhammad Kamal Zubair \\ IAIN Parepare \\ muhammadkamalzubair@iainparepare.ac.id \\ Mukhtar Yunus \\ IAIN Parepare \\ mukhtaryunus@iainparepare.ac.id
}

\begin{abstract}
Buying and selling activities is one of the activities of human life as an activity to meet needs. Islam does not justify any means of buying and selling, but also very much in need of ethics. Ethics is a set of moral principles that distinguish good from bad and normative. It plays the role of determining what must be done or not to be done by individuals or groups. In the ethics of buying and selling, the most important thing is the honesty of the two parties which is the culmination of the morality of faith and the most prominent characteristics of believers. Without honesty, religious life will not stand tall and world life will not go well.

This study aims to determine the practice of buying and selling between fishermen and exporters of fish in the Mallusetasi District, Barru Regency. As well as an analysis of Islamic business ethics on the practice of buying and selling between fishermen and exporters of fish in the Mallusetasi District, Barru Regency. This type of research in this thesis is a qualitative descriptive method. Data in were obtained from primary data and secondary data. The data were collected by observation, interviews, and documentation. The data analysis technique is qualitative data analysis.

The results of this study indicate that the scales of buying and selling activities between fishermen and fishermen are regulated by the fishermen. Determination of the price determined by these collectors sometimes becomes a separate complaint by the fishermen. The number of complaints regarding the sale and purchase process carried out with the container. This is still a problem that often occurs moreover when fishermen have no other place to sell their fish. The practice of buying and selling examined by the
\end{abstract}


Al Maidah Nur, Muhammad Kamal Zubair, Mukhtar Yunus

author faces many problems. The location of the problem is the application of Islamic business ethics in export fish trading activities. Most activities of buying and selling activities in the district Mallusetasi re not in accordance with the principles of Islamic business ethics.

Keywords: Buy and Sale, Export, Business Ethics, Fisherman

Abstrak

Kegiatan jual beli merupakan salah satu aktivitas kehidupan manusia sebagai kegiatan untuk memenuhi kebutuhan. Islam tidak menghalalkan segala cara dalam jual beli, tetapi juga sangat di perlukan etika. Etika merupakan seperangkat prinsip moral yang membedakan yang baik dari yang buruk dan bersifat normative. Ia berperan menentukan apa yang harus di lakukan atau tidak boleh dilakukan oleh individu maupun kelompok. Di dalam etika jual beli, salah satu hal terpenting adalah adanya kejujuran dari dua belah pihak yang merupakan puncak moralitas iman dan karakteristik yang paling menonjol dari orang-orang beriman. Tanpa adanya kejujuran, kehidupan agama tidak akan berdiri tegak dan kehidupan dunia tidak berjalan dengan baik.

Penelitian ini bertujuan untuk mengetahui praktik jual beli antara nelayan dan penadah ikan ekspor di Kecamatan Mallusetasi Kabupaten Barru. Serta analisis etika bisnis Islam terhadap praktik jual beli antara nelayan dan penadah ikan ekspor di Kecamatan Mallusetasi Kabupaten Barru. Jenis penelitian yang digunakan dalam skripsi ini adalah metode deskriptif kualitatif. Data dalam penelitian ini diperoleh dari data primer dan data sekunder. Teknik pengumpulan data yang digunakan adalah observasi, wawancara, dan dokumentasi. Adapun teknik analisis datanya yaitu menggunakan analisis data kualitatif.

Hasil penelitian ini menunjukkan bahwa penagturan timbangan pada kegiatan jual beli antara penadah dan nelayan diatur oleh pihak penadah. Penentuan harga yanag ditentukan oleh penadah ini terkadang menjadi keluhan tersendiri oleh pihak nelayan. Banyak keluhan mengenai proes jual beli yang dilakukan dengan penadahnya. Hal ini masih menjadi permasalahan yang sering terjadi. Terlebih lagi, ketika nelayan tidak memiliki tempat lain untuk menjual ikannya. Pada praktik jual beli yang di teliti oleh penulis, masih banyak terdapat permasalahan. Letak permasalahanannya adalah pada penerapan etika bisnis Islam dalam kegiatan jual beli ikan ekspor. Pada kegiatan jual beli di Kec. Mallusetasi hampir keseluruhan kegiatannya tidak sesuai dengan prinsip etika bisnis Islam.

Kata Kunci: Jualbeli, Nelayan, Ekspor, Etika Bisnis Islam

\section{A. Pendahuluan}

Islam pada dasarnya memiliki sebuah pedoman untuk mengarahkan umatnya dalam melaksanakan setiap aktifitas baik itu hubungan dengan Allah maupun antar sesama manusia. Kegiatan jual beli merupakan salah satu sarana untuk memenuhi kebutuhan hidup antar sesama manusia. ${ }^{1}$. Secara syar'i telah digariskan, berdasarkan firman Allah SWT., dalam Q.S. An-Nisa/4: 29

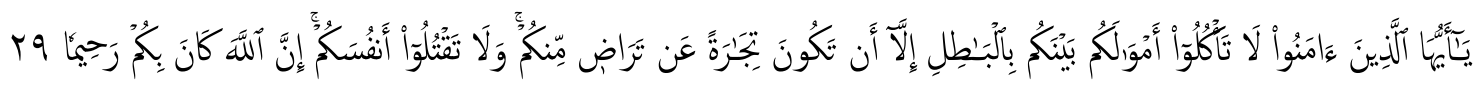

Terjemahnya:

"Hai orang-orang yang beriman, janganlah kamu saling memakan harta sesamamu dengan jalan yang batil, kecuali dengan jalan perniagaan yang berlaku dengan suka sama-suka di antara kamu. dan janganlah kamu membunub dirimu; Sesunggubnya Allah adalah Maha Penyayang kepadamu". ${ }^{2}$

${ }^{1}$ Muhammad dalimin, Etika \& perlindungan Konsumen Dalam Ekonomi Islam, (Yogyakarta: BPEE-Yogyakarta, 2005$)$, h. 43. ${ }^{2}$ Kementerian Agama Republik Indonesia, Al-Quran dan Terjemahan, h. 107. 
Ayat tersebut menjelaskan prinsip tentang perdagangan. Pernyataan yang mengatakan "cara yang salah atau bathil" berhubungan dengan praktik-praktk yang bertentangan dengan syariah dan secara moral tidak halal. Jual beli merupakan sebuah proses di mana terjadinya pertukaran kepentingan sebagai keuntungan tanpa melakukan penekanan yang tidak dihalalkan atau tindakan penipuan terhadap kelompok lain. Ayat di atas menekankan perbuatan baik dalam jual beli. Ini berarti tidak boleh ada rasa tidak senang atau perbedaan antara golongan-golongan dalam hubungan bisnis $^{3}$.

Di dalam etika jual beli, salah satu hal terpenting adalah kejujuran dari dua belah pihak yang merupakan puncak moralitas iman dan karakteristik yang paling menonjol dari orang-orang beriman. Tanpa adanya kejujuran, kehidupan agama tidak akan berdiri tegak dan kehidupan dunia tidak berjalan dengan baik. Sebaliknya, kebohongan adalah pangkal cabang kemunafikan. Cacat dalam jual beli yang paling banyak memperburuk citra adalah kebohongan, manipulasi, dan mencampur adukkan kebenaran dengan kebathilan, baik secara dusta atau menarangkan spesifikasi barang dagangan dan mengunggulkannya atas yang lainnya ${ }^{4}$.

Islam tidak menghalalkan segala cara dalam jual beli tetapi juga sangat diperlukan etika. Etika merupakan seperangkat prinsip moral yang membedakan yang baik dari yang buruk dan bersifat normatif. Ia berperan menentukan apa yang harus di lakukan atau tidak boleh dilakukan oleh individu maupun kelompok 5 .

Kegiatan jual beli merupakan salah satu aktivitas kehidupan manusia sebagai kegiatan untuk memenuhi kebutuhan, baik yang berupa manfaat suatu barang, maupun jasa. Setiap manusia memiliki kebebasan dalam melakukan perdagangan sebagai bentuk pemenuhan akan kebutuhan sehari-hari.

Kegiatan perdagangan memiliki bentuk yang beragam, di antaranya jual beli ikan ekspor yang dilakukan di Kecamatan Mallusetasi, Barru. Kondisi geografis daerah tersebut yang berdekatan dengan laut menjadi faktor utama dalam kegiatan mata pencarian masyarakat. Masyarakat di daerah tersebut dominan bekerja sebagai nelayan. Kegiatan jual beli hasil tangkapan lautpun juga dilakukan di daerah tersebut ${ }^{6}$.

Berdasarkan ajaran Islam, kegiatan jual beli harus menghidari hal-hal yang akan merugikan salah satu pihak. Etika bisnis Islam telah mengatur ketentuan dasar yang harus diikuti, yaitu prinsip tauhid, keseimbangan (keadilan), kehendak bebas dan tanggung jawab.

Pada kenyataannya, kegiatan penadah ikan guna sebagai bahan utama ekspor membuat para nelayan bingung. Para penadah tersebut terkadang membeli tanpa memperhatikan ikan yang di bawah, terkadang pula membeli dengan banyak syarat-syarat lainnya. Para nelayan yang dalam hal ini sebagai penjual menjadi kebingungan. Penadah tersebut tidaklah memiliki kriteria tersendiri dalam penadahan ikan sebagai contohnya pada penentuan harga. Terkadang perubahan harga terjadi tanpa adanya pemberitahuan terlebih dahulu kepada pihak nelayan. Selain itu, timbangan juga menjadi salah satu permasalahan yang sampai saat ini masih sering terjadi.

Dari permasalahan tersebut, yang menjadi hal menarik bagi penulis untuk diteliti adalah perilaku para penadah ikan hasil tangkapan nelayan tersebut. Tujuan tulisan ini adalah menganalisis Etika Bisnis Islam terhadap Perilaku Penadah Ikan Ekspor di Kecamatan Mallusetasi Kabupaten Barru.”.

\footnotetext{
${ }^{3}$ Rahman, Penjelasan lengkap Hukum-Hukum Allah (Syariah) (Jakarta: Raja GrafindoPersada, 2002), h. 444. ${ }^{4}$ Yusuf Qardhawi,Peran Nilai dan Moral dalam Perekonomian Islam (Jakarta: Robbani Press, 2004), h. 42.

${ }^{5}$ Muhammad Majdy Amiruddin, 'Khiyār (Hak Untuk Memilih) Dalam Transaksi On-Line: Studi Komparasi Antara Lazada, Zalara Dan Blibli', Falah: Jurnal Ekonomi Syariah, 1.1 (2016), 47-62.

${ }^{6}$ Rafik Isa Beekum, Etika Bisnis Islami (Yogyakarta: PustakaPelajar, 2004), h. 3.
} 


\section{B. Dikusi dan Pembahasan}

\section{Praktik Jual Beli Antara Nelayan dan Penadah Ikan Ekspor di Kecamatan Mallusetasi Kabupaten Barru}

Dalam kehidupan bermasyarakat, perdagangan atau jual beli adalah hal yang dianggap biasa. Pada zaman dahulu, jual beli diartikan tukar menukar barang dengan barang orang lain sesuai dengan kesepakatan yang dibuat. Praktik penjualan ikan ekspor di Kecamatan Mallusetasi berjalan sebagaimana mestinya. Praktik penjualan ikan ekspor dilakukan melalui dua cara yaitu penadah yang mendatangi nelayan ataukah nelayan yang datang ke tempat penadah.

Nelayan menurut Undang-Undang No. 9 Tahun 1985 adalah orang yang mata pencahariannya melakukan penangkapan ikan. Juragan adalah pemilik perahu. Motor dan alat tangkap atau sebagai manajer. Nelayan adalah mereka yang mata pencaharian pokoknya di bidang penangkapan ikan dan penjualan ikan yang hidup di daerah pantai untuk menangkap ikan diperlukan alat yang memadai misalnya: perahu, pancing, jala atau jaring.

Secara geografis, masyarakat nelayan adalah masyarakat yang hidup, tumbuh dan berkembang di kawasan pesisir, yakni suatu kawasan transisi antara wilayah darat dan laut. Nelayan adalah kelompok masyarakat yang kehidupannya tergantung langsung pada hasil laut, baik dengan cara melakukan penangkapan ataupun budi daya. Mereka pada umumnya tinggal di pinggir pantai, sebuah lingkungan pemukiman yang dekat dengan lokasi kegiatannya.

Dalam praktik jual beli antara nelayan dan penadah di Kecamatan Mallusetasi, terkadang penadah yang mendatangi para nelayan untuk membeli ikan. Namun tidak menutup kemungkinan nelayan yang mendatangi penadah untuk menjual tangkapannya.

"Jadi, terkadang kami yang membawa langsung ke penadah untuk menjual ikan kami. Tetapi

terkadang, ketika ikan kami sudah banyak terkumpul kami biasa menelpon agar pengepul datang

ke tempat nelayan."

Proses penjualan ikan ekspor ke penadah dilakukan ketika nelayan memiliki persediaan. Hal ini dikarenakan mempermudah dan mempersingkat waktu serta biaya. Hal ini sebagai mana Wawancara dengan salah satu nelayan.

"Jadi, kalau kami mendapatkan ikan ekspor kami menjual ke penadah. Karena hasilnya berbeda

ketika dijual di pasar. Bila di bawah ke tempat penadah harganya lebih tinggi dibandingkan di pasar."

Hal senada juga diungkapkan oleh pihak penadah yang menjelaskan mengenai proses jual beli ikan ekspor di Kec. Mallusetasi.

"Pada prosesnya, terkadang kalau nelayan menelpon bahwa ada persediaan ikan ekspor saya

datang langsung ke rumahnya. Tapi terkadang nelayan yang datang ketempat saya. Karena pada dasarnya persediaan ikan ekspor ini tidak setiap saat ada."

Kegiatan jual beli ikan ekspor ini memberikan keuntungan yang memuaskan karena harga yang lebih tinggi dibandingkan ketika dijual di pasar. Banyak masyarakat atau nelayan yang melakukan hal ini. Keuntungan yang besar bisa memasok keuangan keluarga untuk mendapatkan hal-hal yang mungkin diinginkan. 
Di zaman seperti sekarang ini, manusia tidak bisa terlepas dari adanya internet. Hal seperti ini juga dimanfaatkan oleh nelayan yang mengerti akan kecanggihan teknologi. Sebagaimana Wawancara dengan salah seorang nelayan:

"Terkadang saya mengecek mengenai perubahan harga ikan, jadi saya mecarinya di internet atau langsung menelpon pihak di pusat pengelola ikan ekspor. Hal ini agar tidak ada kebohongan yang dilakukan salah satu pihak bila pihak lainnya sudah mengetahui harga yang sebenarnya"

Berdasarkan Wawancara penulis dengan nelayan dan penadah, maka praktik jual beli ikan ekspor dapat digambarkan sebagai berikut:

a. Nelayan melakukan penjualan ke penadah

b. Penadah datang ke tempat nelayan

c. Penentuan harga berdasarkan naik turunnya dollar

Jadi penjualan ikan ekspor dilakukan dengan dua cara apakah nelayan yang mendatangi penadah secara langsung rumah nelayan. Selain itu penentuan harga bergantung kepada perubahan nilai dollar. Pada proses jual beli, ada beberapa hal yang dilarang agar tidak merugikan salah satu pihak ataupun kedua belah pihak. Para nelayan terkadang merasa dirugikan oleh beberapa hal yang dilakukan oleh penadah. Pada dasarnya, prinsip-prinsip jual beli telah diatur dalam Islam, yaitu:

\section{a. Kejujuran}

Konsep ini membuat ketenangan hati bagi orang yang melaksanakannya. Kejujuran yang ada pada diri seseorang membuat orang lain senang berteman dan berhubungan dengan dia. Di dalam bisnis, pemupukan relasi sangat mutlak diperlukan sebab relasi ini sangat membantu kemajuan bisnis jangka panjang.

Pada proses penerapan kejujuran yang dilakukan oleh penadah, terdapat beberapa permasalahan yang dikeluhkan oleh pihak nelayan dalam prosesnya.:

"Jadi terkadang yang kami permasalahkan adalah perubahan harga yang mendadak. Terkadang kami datang membawa ikan. penadah hanya mengatakan bahwa harganya turun jadi kami tidak bisa melakukan apa-apa"”.

"Memang kalau masalah harga terkadang kami dirugikan. Kami mau pindah tempat lain tapi karena biaya perjalanan, kami mengurungkan niat ${ }^{8}$ ",

"Kami nelayan jarang mengetahui tentang permasalahan naik turunnya dollar. Terkadang kami protes tapi pengepul juga tidak menjelaskan secara rinci hanya mengatakan kalau dollar turun jadi harga ikan turun"”

"Jadi konfirmasi dari pihak pengepul kurang. Kami kaget karena tidak adanya konfirmasi sebelumnya. ${ }^{10}$,

Berdasarkan Wawancara dengan pihak nelayan, penulis mendapatkan simpulan bahwa bentuk jual beli antara nelayan dan penadah mengalami banyak permasalahan. Banyaknya keluhan dari pihak nelayan mengenai kejujuran dari pihak penadah ikan telah melanggar salah satu prinsip Islam. Syariah Islam sangat memperhatikan nilai-nilai kejujuran dalam bertransaksi, seperti penjelasan penjual atas

\footnotetext{
${ }^{7}$ Hasil Wawancara dengan Sandi (nelayan Mallusetasi), 12 Oktober 2017

${ }^{8}$ Hasil Wawancara dengan Tardi (nelayan Mallusetasi), 12 Oktober 2017

${ }^{9}$ Hasil Wawancara dengan Lukman (nelayan Mallusetasi), 12 Oktober 2017

${ }^{10}$ Hasil Wawancara dengan Saleh (penadah ikan Mallusetasi), 12 Oktober 2017
} 
cacat barang yang dijual. Apabila dalam barang dagangan terdapat kerusakan dan penjual tidak memeberi penjelasan kepada penadah, maka penjual telah melakukan pelanggaran syariah. Memberikan hak kepada penadah untuk mengembalikan barang ketika ditemukan kerusakan yang dapat mengurangi nilai intrinsik sebuah komoditas serta memberikan kebebasan dalam memilih. Sama halnya mengenai penjelasan yang kurang dari pihak penadah yang merugikan pihak nelayan.

\section{b. Adil dalam takaran dan timbangan}

Takaran adalah alat yang digunakan untuk mengetahui kuantita suatu berdasarkan volume maupun beratnya. Dalam aktifitas bisnis, takaran biasanya dipakai untuk mengukur satuan dasar ukuran isi barang cair, sedangkan timbangan digunakan untuk mengukur satuan berat. Takaran dan timbangan adalah dua macam alat ukur yang diberikan perhatian untuk benar-benar dipergunakan secara tepat dalam perspektif ekonomi syariah ${ }^{11}$.

Pada kegiatan jual beli antara penadah dan nelayan, pengaturan timbangannya diatur oleh pihak penadah. Penentuan harga ditentukan oleh penadah ini terkadang menjadi keluhan tersendiri oleh pihak nelayan.

"Jadi terkadang saat kami sudah membawa ikan, timbangannya terkadang berubah. Kan biasanya kami penimbang dulu, misalnya ditimbangan kami $1,2 \mathrm{~kg}$. Nanti sampai di tempat penadah biasanya berkurang jadi $1 \mathrm{~kg}$ saja. ${ }^{12}$,

"Biasanya antara satu penadah dan yang lain itu berbeda harga. Terkadang di sini harganya belinya tinggi tapi timbangannya tidak beres. Ada juga yang harganya belinya rendah tapi timbangannya pas. Jadi kami sebagai nelayan bingung. ${ }^{13}$,

"Timbangannya penadah kadang jadi permasalahan kami karena hasilnya berbeda. Kami tidak tahu mana yang benar timbangannya. Kalaupun ada yang beres timbangannya tempatnya jauh, Kami masih berpikir dua kali karena tambah biaya lagi ${ }^{14,}$

Berdasarkan Wawancara dengan para nelayan, penulis menemukan keluhan mengenai proes jual beli yang dilakukan dengan penadahnya. Hal ini masih menjadi permasalahan yang sering terjadi. Terlebih lagi, ketika nelayan tidak memiliki tempat lain untuk menjual ikannya. Selain itu, dalam melakukan jual beli, berlaku jujur dalam menakar timbangan haruslah dilakukan. Jujur dalam pengertian yang lebih luas yaitu tidak berbohong, tidak menipu, tidak mengada-ada, fakta, tidak berkhianat, serta tidak pernah ingkar janji1

Islam mengatur permasalahan takaran dalam timbangan. Kecurangan menakar dan menimbang mendapat perhatian khusus dalam al-Qur'an karena praktik semacam ini termasuk merampas hak orang lain. Selain itu, praktik semacam ini juga menimbulkan dampak yang sangat buruk dalam dunia perdagangan yaitu timbulnya ketidakpercayaan penadah terhadap pedagang yang curang. Oleh karena

\footnotetext{
${ }^{11}$ Ahmad Mujahidin, Ekonomi Islam: Sejarah, Konsep, Instrumen, Negara dan Pasar, (Jakarta: PT. Raja Grafindo Persada, 2014), h. 159.

12 Hasil Wawancara dengan Sandi (nelayan Mallusetasi), 12 Oktober 2017

${ }^{13}$ Hasil Wawancara dengan Tardi (nelayan Mallusetasi), 12 Oktober 2017

${ }^{14}$ Hasil Wawancara dengan Lukman (nelayan Mallusetasi), 12 Oktober 2017

${ }^{15}$ Johan Arifin, Etika Bisnis Islam (Semarang: Walisongo Press, 2009), h. 15.
} 
itu, pedagang yang curang pada saat menakar dan menimbang mendapat ancaman siksa di akhirat ${ }^{16}$. Allah swt., berfirman dalam Q.S. Al-Muthaffifin/83: 1-3.

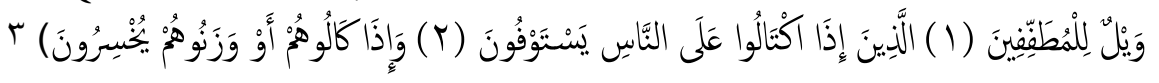

Terjemahnya:

"Celakalah bagi orang-orang yang curang (dalam menakar dan menimbang) (1) Yaitu orang-orang yang apabila menerima takaran dari orang lain mereka minta dicukupkan (2) Dan apabila mereka menakar atau menimbang (untuk orang lain), mereka mengurangi (3)". ${ }^{17}$

Ayat ini memberi peringatan keras kepada para pedagang yang curang. Mereka dinamakan mutaffifin. Dalam bahasa Arab, mutaffifin berasal dari kata tatfif atau Tafafah, yang berarti pinggir atau bibir sesuatu. Pedagang yang curang itu dinamai mutafifin karena ia menimbang atau menakar sesuatu hanya sampai bibir timbangan tidak sampai penuh kepermukaan. Dalam ayat di atas, perilaku curang dipandang sebagai pelanggaran moral yang sangat besar dan perilakunya diancam hukuman berat, yaitu masuk neraka Wail ${ }^{18}$. Adanya kecurangan dalam menakar dan menimbang terjadi karena ketidakjujuran yang didorong oleh keinginan mendapat keuntungan yang lebih besar tanpa peduli dengan kerugian orang lain.

Selain ayat tersebut, Al-Qur'an di dalam ayat lain juga mengatur mengenai takaran timbangan. Dalam hal menimbang dan menakar barang yang diperdagangkan, para penadah sering melakukan kecurangan yang merugikan para nelayan. Hal ini tidak sejalan denga firman Allah swt., dalam Q.S AsySyu'araa:

"Sempurnakanlah takaran dan janganlah kamu termasuk orang- orang yang merugikan. Dan timbanglah dengan timbangan yang lurus. Dan janganlah kamu merugikan manusia pada hak-haknya dan janganlah kamu merajalela di muka bumi dengan membuat kerusakan".

\section{c. Menjual Barang yang Baik Mutunya}

Salah satu cacat etis dalam perdagangan adalah tidak transparan dalam hal mutu yang berarti mengabaikan tanggung jawab moral dalam dunia bisnis. Padahal tanggungjawab yang diharapkan adalah tanggungjawab yang seimbang antara memperoleh keuntungan dan memenuhi norma-norma dasar masyarakat baik berupa hukum, maupun etika atau adat.

Pada kegiatan jual beli ikan ekspor antara penadah dan nelayan, ciri dan karakter ikan sangatlah diperhatikan. Hal ini dikarenakan, ciri dan karakteristik ikan mempengaruhi harga ikan terebut.

"Mengenai mutu ikan, kami memasang patokan ciri tersendiri. Karena dari perusahaan yang di makassar mengatur bagaimana ikan yang layak untuk diekspor. Jadi setiap tahunnya ada perubahan. Kalau sekarang asal tidak cacat bagian dada sampai ekor itu bisa diambi1 ${ }^{19}$."

Berdasarkan Wawancara dengan salah satu penadah ikan di Kec. Mallusetasi tersebut, dapat dikatakan bahwa ciri yag mereka tetapkan itu berdasarkan peraturan pusatnya. Mengenai permasalahan

\footnotetext{
${ }^{16}$ Veithzal Rivai, dkk, Islamic Bussines And Economic Ethics mengacu pada al-Quran dan Mengikuti Jejak Rasulullah saw dalam Bisnis, Keuangan dan Ekonomi, h. 411.

${ }^{17}$ Kementerian Agama Republik Indonesia, Al-Quran dan Terjemahan, h. 878

${ }^{18}$ Ahmad Mujahidin, Ekonomi Islam: Sejarah, Konsep, Instrumen, Negara dan Pasar, h. 161.

${ }^{19}$ Ahmad Mujahidin, Ekonomi Islam: Sejarah, Konsep, Instrumen, Negara dan Pasar, h. 161 .
} 
ciri-ciri, dari pihak nelayan setiap tahunnya memberikan masukkan kepada pihak penadah agar nantinya disampaikan ke pihak pusat. Para nelayan mengajukan keluhan kerugian yang biasa dialami jika ciri-ciri pengambilannya merugikan nelayan.

\section{d. Adanya Hak Pilih (Khiyar)}

Dalam proses perdagangan atau jual beli, Islam mengatur sebuah intrumen yang bernama khiyar. Sederhananya, khiyar berarti memilih apakah akan meneruskan atau membatalkannya jual beli. Khiyar dibagi menjadi 3 yaitu: Pertama, Khiyar Majlis (Penjual dan penadah mempunyai hak pilih akan melanjutkan jual beli atau membatalkannya selama keduanya masih dalam suatu tempat (majlis). Kedua, Khiyar syarat (Penjual dan penadah mensyaratkan (masyru') didalam pelaksanaan jual beli, seperti dalam jual beli mobil dengan harga 350 juta rupiah dengan persyaratan hak pilih selama 3 hari. Ketiga, Khiyar 'aib (dalam perdagangan atau jual beli disyaratkan akan terjaminnya kesempurnaan barang yang diperjualbelikan yaitu tidak ada cacatnya). Apabila kondisi suatu barang tidak baik atau ada cacat sesuai dengan perjanjian boleh dikembalikan ${ }^{20}$.

Pada proses hak pilih d isini, pihak nelayan merasa kurangnya hak pilih karena keterbatasan pemilihan. Hal ini dikarenakan para nelayan memikirkan jauhnya tempat, biaya transportasi, masalah timbangan yang berbeda ditiap para penadah.

"Jadi kami nelayan, terkadang tidak bisa memilih jalan lain selain menjualnya di penadah itu. Apalagi tempat penadah yang satu dengan yang lainnya jauh. Karena kami juga berpikir dua kali kalau menambah biaya lagi." 21

"Kami juga tidak bisa memilih karena dari pada ikannya dijual ke pasar lebih murah lagi. Kalau di penadah bisa dapat ratusan ribu tapi kalau dijual dipasar harganya jatuh kadang cuman puluhan ribu. Jadi daripada rugi mau tidak mau kami menjual di penadah." 22

“Terkadang kami merasa penadah memainkan harga, jadi mau tidak mau kami jualnya disana."

Berdasarkan Wawancara dengan nelayan tersebut, para nelayan dalam proses jual beli tidak memiliki hak pilih untuk menjual ikannya. Ketika dikonfirmasi kepada pihak penadah, mereka mengatakan tidak pernah memaksa karena memang tidak ada perjanjian.

"Jadi sebenarnya kami memberi keleluasaan kepada para nelayan, kami tidak memaksakan harus menjual ikannya kepada kami" 23

Di dalam syariat Islam seharusnya dalam proses jual beli dibarengi dengan adanya khiyar atau hak pilih. Hal ini di maksudkan agar kedua belah pihak mendapatkan kepuasan dalam transaksi jual beli. Pada proses jual beli ikan di Kec. Mallusetasi hak pilih terbatas dikarenakan hal-hal tertentu

\section{Analisis Etika Bisnis Islam terhadap Praktik Jual Beli antara Nelayan dan Penadah Ikan Ekspor di Kecamatan Mallusetasi Kabupaten Barru}

Nelayan menurut Undang-Undang No. 9 Tahun 1985 adalah orang yang mata pencahariannya melakukan penangkapan ikan. Juragan adalah pemilik perahu, motor dan alat tangkap atau sebagai manajer. Nelayan adalah mereka yang mata pencaharian pokoknya di bidang penangkapan ikan dan

\footnotetext{
${ }^{20}$ Ismail Nawawi, Fikih Muamalah Klasik dan Kontemporer (Bogor: Ghalia Indonesia, 2012), h. 85-87.

${ }^{21}$ Hasil Wawancara dengan Lukman (nelayan Mallusetasi), 12 Oktober 2017

22 Hasil Wawancara dengan Ardi (nelayan Mallusetasi), 12 Oktober 2017

${ }^{23}$ Hasil Wawancara dengan Anci (nelayan Mallusetasi), 12 Oktober 2017
} 
penjualan ikan yang hidup di daerah pantai untuk menangkap ikan diperlukan alat yang memadai misalnya: perahu, pancing, jala atau jaring.

Secara geografis, masyarakat nelayan adalah masyarakat yang hidup, tumbuh dan berkembang di kawasan pesisir, yakni suatu kawasan transisi antara wilayah darat dan laut. Nelayan adalah suatu kelompok masyarakat yang kehidupannya tergantung langsung pada hasil laut, baik dengan cara melakukan penangkapan ataupun budi daya. Mereka pada umumnya tinggal di pinggir pantai, sebuah lingkungan pemukiman yang dekat dengan lokasi kegiatannya.

Etika bisnis merupakan suatu bidang usaha yang dilakukan secara baik dan benar sesuai dengan moral dan melakukan segala sesuatu dengan penuh tanggung jawab yang diterapkan dalam linkup perdagangan dan bidang usaha.

Kata "bisnis" dalam Bahasa Indonesia diserap dari kata "business" dari Bahasa Inggris yang berarti kesibukan. Dalam kamus Bahasa Indonesia, bisnis di artikan sebagai usaha dagang, usaha komersial di dunia perdagangan dan bidang usaha ${ }^{24}$. Dalam kamus umum, Bahasa Indonesia berdagang yaitu berniaga; jual beli ${ }^{25}$. Perdagangan atau jual beli menurut bahasa berarti al Bai', al- Tijarah, al-Mubadalah, sebagaimana Allah swt berfirman dalam Q.S. Faathir/35 : 29.

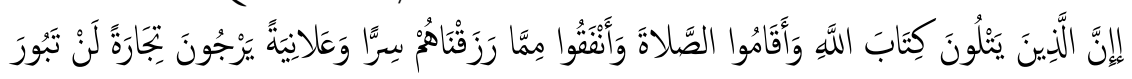

Terjemahnya:

"Sesunggubnya orang-orang yang selalu membaca Kitab Allah dan mendirikan shalat dan menafkabkan sebahagian dari rękei yang kami anuge- rabkan kepada mereka dengan diam-diam dan terang-terangan, mereka itu mengharapkan perniagaan yang tidak akan merugi. ${ }^{26 \text { ", }}$

Ayat diatas menjelaskan bahwa perniagaan dilaksanan dengan ikhlas dan tanpa riya'. Mereka itu ibarat pedagang yang tidak akan merugi tetapi memperoleh pahala yang berlipat ganda, sebagai karunia Allah swt karena mereka mengetahui bahwa apa yang ada di sisi Allah adalah lebih baik dari apa yang mereka infaqkan itu mereka berdagang dengan perdagangan yang menguntungkan yang terjamin keuntungannya.

Mereka berniaga dengan Allah karena berniaga dengan Allah adalah perniagaan yang paling menguntungkan. Mereka memperdagangkan itu dengan tujuan akhirat karena akhirat itu adalah perdagangan yang paling menguntungkan. Perdagangan yang akan mengantarkan mereka untuk mendapatkan balasan yang utuh bagi mereka serta mendapatkan tambahan anugerah dari Allah swt ${ }^{27}$.

Ketentuan dasar etika bisnis ini merupakan turunan dari hasil penerjemahan kontemporer akan konsep-konsep fundamental dari nilai para pebisnis muslim untuk menentukan prinsip-prinsip yang dianut dalam menjalankan bisnisnya ${ }^{28}$. Dasar-dasar tersebut adalah sebagai berikut:

\footnotetext{
24Johan Arifin, Etika Bisnis Islami (Semarang: Walisongo Press, 2009), h. 20.

${ }^{25}$ W.J.S. Poerwadarminta, Kamus Umum Bahasa Indonesia (Jakarta : Balai Pustaka, Edisi Ketiga, 2006), h. 255.

${ }^{26}$ Kementerian Agama Republik Indonesia, Al-Quran dan Terjemahan, h. 621.

${ }^{27}$ Sayyid Quthb, Tafsir Fi Zhilalil Qur'an Jilid 11 (Jakarta : Gema Insani, 2004), h. 365.

${ }^{28}$ Faisal Badroen, Etika Bisnis Dalam Islam (Jakarta: Prenada Media Group, 2006), h. 88-89.
} 


\section{a. Tauhid}

Tauhid merupakan landasan yang sangat filosofis yang dijadikan sebagai fondasi utama setiap langkah seorang muslim yang beriman dalam menjalankan fungsi kehidupannya, seperti yang dinyatakan oleh firman Allah di dalam Q.S Al-An'am/ 6: 126-127, yaitu

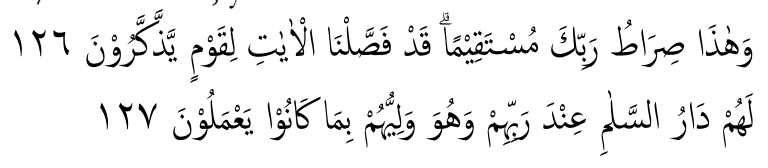

Terjemahnya:

"Dan inilah jalan Tubanmu, (jalan) yang lurus. Sesunggubnya Kami telah menjelaskan ayat-ayat (kami) kepada orang-orang yang mengambil pelajaran (126). Bagi mereka (disediakan) Darussalam (surga) pada sisi Tubannya dan Dialah pelindung mereka disebabkan amalamal saleh yang selalu mereka kerjakan(127)." ${ }^{29}$

Berdasarkan ayat tersebut, proses jual beli haruslah mencerminkan sifat dan perilaku yang baik seperti sifat bijak, ihsan, rakhman dan rakhim, adil, seimbang dan lain-lain yang patut ditiru oleh manusia dalam mengelola bisnisnya terutama dalam kaitan pemberdayaan sumber daya yang dibutuhkan dan diperlukan. Landasan tauhid ini bertitik tolak pada keridlaan Allah swt., dan tata cara yang dilakukan sesuai dengan syariah-Nya.

Selain itu, prinsip ketauhidan ini mengandung perpaduan keseluruhan aspek-aspek kehidupan muslim baik dalam bidang ekonomi, politik, sosial dan lain sebagainya yang menjadi satu ${ }^{30}$. Sikap dan perbuatan yang lurus yang dinyatakan dalam surat ini secara logis mencerminkan perilaku yang benar, baik sesuai dengan perintah-perintah Allah swt. dan sesuai dengan tolak ukur dan penilaian Allah swt. Bila dilihat dari penerapan jual beli yang ada di Kec. Mallusetasi, konsep ketauhidan dari segi perilaku yang dimiliki penadah masih rendah karena banyak nelayan yang meragukan di setiap transaksi jual beli baik dari timbangan maupun penetuan harga yang ditetapkan oleh penadah.

Hal yang terjadi dalam proses jual beli di Kec. Mallusetasi tersebut tidak sejalan dengan Q.S AtTaubah/9:105:

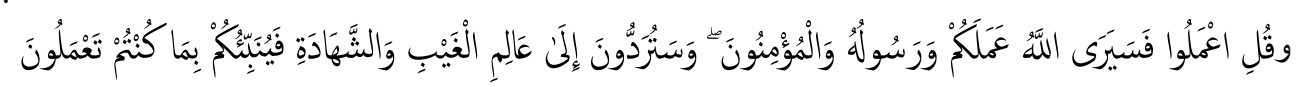

Terjemahnya:

"dan Katakanlab: "Bekerjalah kamu, Maka Allah dan Rasul-Nya serta orang-orang mukmin akan melihat pekerjaanmu itu, dan kamu akan dikembalikan kepada (Allah) yang mengetabui akan yang ghaib dan yang nyata, lalu diberitakan-Nya kepada kamu apa yang telab kamu kerjakan". ${ }^{31}$

Dari ayat di atas dapat diketahui bahwa Allah mengetahui segala hal yang dikerjakan oleh umatnya. Oleh karenanya itu, penadah dalam hal ini yang memiliki rasa kurangnya ketauhidan dalam pelaksanaan jual beli haruslah mengetahui hal apa yang dilarang oleh Allah swt. agar tidak lagi melakukan kegiatan yang tidak mencerminkan sikap ketauhidan.

${ }^{29}$ Kementerian Agama Republik Indonesia, Al-Quran dan Terjemahan, h. 194.

30Johan Arifin, Etika Bisnis Islam (Semarang: Walisongo Press, 2009), h. 133.

${ }^{31}$ Kementerian Agama Republik Indonesia, Al-Quran dan Terjemahan, h. 64 


\section{b. Keseimbangan (keadilan)}

Dalam beraktifitas di dunia bisnis, Islam mengharuskan untuk berbuat adil. Pengertian adil dalam Islam diarahkan agar hak orang lain, hak lingkungan sosial dan hak Allah dan Rasul-Nya berlaku sebagai stakeholder dari perilaku adil seseorang. Semua hak-hak tersebut harus ditempatkan sebagaimana mestinya (sesuai aturan syariah). Tidak mengakomodir salah satu hak di atas, dapat menempatkan tersebut pada kezaliman. Karenanya, orang yang adil akan lebih dekat kepada ketakwaan. Berlaku adil akan dekat dengan takwa sehingga dalam perniagaan, Islam melarang untuk menipu walaupun hanya sekedar membawa pada kondisi yang menimbulkan keraguan sekalipun.

Kondisi ini dapat terjadi seperti adanya gangguan mekanisme pasar atau karena adanya informasi penting mengenai transaksi yang tidak diketahui oleh salah satu pihak. Gangguan pada mekanisme pasar dapat berupa gangguan dalam penawaran dan gangguan dalam permintaan. Islam mengharuskan penganutnya untuk berlaku adil dan berbuat kebajikan. Dalam perniagaan, persyaratan adil yang paling mendasar adalah dalam menentukan mutu (kualitas) dan ukuran (kuantitas) pada setiap takaran maupun timbangan $^{32}$.

Keseimbangan adalah menggambarkan dimensi horizontal ajaran Islam dan berhubungan dengan harmoni segala sesuatu di alam semesta. Keseimbangan dalam transaksi misalnya, adalah transaksi yang setara, adil dan seimbang ${ }^{33}$. Pada kegiatan jual beli ikan ekspor di Kecamatan Mallusetasi, keseimbangan yang setara, adil dan seimbang masih belum dapat tercapai karena masih banyaknya keluhan yang dikatakan oleh para nelayan. Para nelayan merasakan ketika melakukan proses penjualan kepada pihak penadah tidak mendapatkan harga yang sesuai dengan yang diharapkan.

"Kami mendapatkan hasil yang tidak sesuai dengan harapan kami, terkadang kami menimbang ukurannya sekian tetapi ketika sampai di penadah ukurannya berubah. ${ }^{34,}$

"Perubahan harga biasanya yang menyebabkan tidak setaranya apa yang kami tawarkan dan apa yang kami peroleh dari pihak penadah. Pihak penadah juga hanya mengatakan harganya sedang turun jadi mau tidak mau tetap menjualnya." 35

Berdasarkan wawancara tersebut, dapat dilihat bahwa para nelayan mengeluhkan mengenai keseimbangan antara modal dan hasil yang diperolehnya. Oleh karena itu, prinsip keseimbangan yang di terapkan dalam Islam tidak bisa terealisasi dengan baik pada kegiatan jual beli antara nelayan dn pihak penadah.

\section{c. Kehendak Bebas}

Manusia diberikan kehendak bebas oleh Allah swt. untuk mengendalikan kehidupannya sendiri dengan tanpa mengabaikan kenyataan bahwa ia sepenuhnya dituntun oleh hukum yang diciptakan Allah swt. Ia diberi kemampuan untuk berpikir dan membuat keputusan untuk memilih apapun jalan hidup yang ia inginkan dan yang paling penting untuk bertindak berdasarkan aturan apapun yang ia pilih. Tetapi sekali ia memilih untuk menjadi seorang muslim, ia harus tunduk kepada Allah swt. Ia menjadi bagian umat secara keseluruhan dan menyadari kedudukannya sebagai khalifah Allah di muka bumi $^{36}$.

\footnotetext{
${ }^{32}$ Faisal Badroen, Etika Bisnis dalam Islam (Jakarta: Prenada Media Group, 2006), h. 91-92.

${ }^{33}$ Muhammad, Etika Bisnis Islam (Yogyakarta: UPP AMP YKPN, 2002), h. 55

34 Hasil Wawancara dengan Anci (nelayan Mallusetasi), 12 Oktober 2017

${ }^{35}$ Hasil Wawancara dengan Ali (nelayan Mallusetasi), 12 Oktober 2017

${ }^{36}$ Muhammad, Etika Bisnis Islami, h. 55-56.
} 
Konsep Islam menekankan bahwa institusi ekonomi seperti pasar dapat berperan efektif dalam kehidupan ekonomi. Hal ini dapat berlaku apabila prinsip persaingan bebas dapat berlaku secara efektif di mana pasar tidak mengharapkan adanya intervensi dari pihak manapun.

Berdasarkan konsep kehendak bebas, baik nelayan maupun pihak penadah haruslah memiliki kehendak bebasnya tersendiri asalkan tidak saling merugikan dan menciderai perekonomian. Para nelayan di Kec. Mallusetasi memiliki kehendak bebas dalam melakukan penjualan kepada pengepul, hal ini berdasarkan wawancara dengan para nelayan:

"Jadi kami menjual kepada pihak penadah, tetapi tidak hanya pada penadah itu saja. Terkadang kami menjual di penadah A kadang kami juga menjual di pendah B" 37

"Biasanya tempat saya menjual ikan itu berubah-rubah. Ini karena terkadang harga yang ditawarkan oleh penadah A lebih tinggi dari penadah B" 38

"Memang kami menjualnya tidak tetap di satu tempat. Kami melihat di mana harga yang lebih tinggi. Tetapi, bukan hanya harga yang menjadi patokan kami, masalah timbangan juga kami pikirkan. Terkadang ada penadah yang harga pembeliannya tinggi tapi timbangannya tidak beres begitu juga sebaliknya." 39

"Terkadang mau tidak mau saya menjual nya di satu penadah karena saya merasa tidak memiliki pilhan lain. Karena kalau harus mencari penadah lain, bisa menambah biaya lagi, belum lagi timbangannya yang bermasalah"

"Kalau menjual ikan di penadah saya hanya menjualnya di penadah itu saja, tidak kepenadah lain. Karena belum tentu ditempat lain harganya lebih tinggi. Selain itu, daripada saya menjualnya di pasar malah lebih rugi" 40

Berdasarkan Wawancara tersebut, kehendak bebas yang dimiliki oleh para nelayan tergantung kepada mereka. Banyak nelayan yang berusaha mencai tempat lain yang lebih tinggi harganya. Tetapi, tidak sedikit nelayan yang langsung menjualnya ke satu penadah.

\section{d. Tanggung Jawab}

Kehendak bebas berkaitan erat dengan aksioma tanggung jawab. Meskipun kedua aksioma itu merupakan pasangan secara alamiah, tetapi itu tidak berarti bahwa hubungan keduanya secara logis atau praktis. Sedemikian saling terkait, sehingga tidak bisa dibedakan satu sama lain. Islam menaruh penekanan yang besar pada konsep tanggung jawab, tetapi itu tidak berarti kurang memperhatikan kebebasan individu. Justru Islam berusaha menetapkan keseimbangan yang tepat di atas keduanya ${ }^{41}$.

Selain kehendak bebas yang dimiliki oleh nelayan, ada juga tanggung jawab yang harus dimiliki agar seimbang dengan kehendak bebasnya. Contoh tanggung jawab yang harus dimiliki oleh nelayan adalah dengan memberikan ikan yang sesuai dengan ciri dan karakteristik yang telah ditentukan.

\footnotetext{
${ }^{37}$ Hasil Wawancara dengan Sandi (nelayan Mallusetasi), 12 Oktober 2017

38 Hasil Wawancara dengan Lukman (nelayan Mallusetasi), 12 Oktober 2017

${ }^{39}$ Hasil Wawancara dengan Ardi (nelayan Mallusetasi), 12 Oktober 2017

${ }^{40}$ Hasil Wawancara dengan Ali (nelayan Mallusetasi), 12 Oktober 2017

${ }^{41}$ Syed Nawab Haider Naqvi, Menggagas Ilmu Ekonomi Islam, (Yogyakarta: Pustaka Pelajar, 2003), h. 46.
} 
"Tidak semua ikan kami bawa ke penadah, hanya ikan yang sesuai dengan karakteristik dan ciri yang telah ditentukan" ${ }^{42}$

"Kalau yang memenuhi karakteristik kami bawa ke penadah, kalau tidak yah kami membawanya ke pasar untuk dijual" 43

Dasar tanggung jawab individu begitu mendasar dalam ajaran-ajaran Islam. Terutama jika dikaitkan dengan kebebasaan ekonomi. Oleh karena itu, tanggug jawab juga harus dimiliki oleh penadah. Berdasarkan Wawancara dengan penadah, mereka mengatakan bahwa mereka melakukan penentuan harga bedasarkan naik turunnya harga.

Akan tetapi, para nelayan menganggap penadah bersikap kurang bertanggung jawab karena mereka tidak memberi informasi terlebih dahulu terkait harga.

"Kami terkadang kecewa dengan pihak penadah mengenai penentuan harga. Perubahan harga yang mendadak membuat kami mau tidak mau tetap menjual ikan ditempat itu." 44

"Jadi terkadang kami sudah sampai di tempat penadah, harganya justru berubah. Penadah kurang bertanggung jawab dalam hal ini." 45

"Mau tidak mau kami tetap menjualnya di penadah itu, meskipun harganya berubah sewaktuwaktu karena sudah tidak ada pilihan lain ${ }^{46 "}$

Berdasarkan Wawancara dengan nelayan tersebut, unsur tanggung jawab dalam etika bisnis Islam belum terlaksana secara baik. Hal ini dikarenakan, pada proses jual beli antara penadah dan nelayan masih kurang sikap tanggung jawab

\section{Simpulan}

1. Kegiatan jual beli ikan ekspor di Kec. Mallusetasi masih mengalami berbagai macam permasalahan yang tidak sesuai dengan prinsip jual beli yang telah diatur dalam masyarakat. Banyaknya keluhan dari pihak nelayan mengenai kejujuran dari pihak penadah ikan telah melanggar salah satu prinsip Islam. syariah Islam sangat memperhatikan nilai-nilai kejujuran dalam bertransaksi, seperti penjelasan penjual atas cacat barang yang dijual. Apabila dalam barang dagangan terdapat kerusakan dan penjual tidak memeberi penjelasan kepada penadah, maka penjual telah melakukan pelanggaran syariah.

2. Pada praktik jual beli yang di teliti oleh penulis, masih banyak terdapat permasalahan. Letak permasalahanannya adalah pada penerapan etika bisnis Islam dalam kegiatan jual beli ikan ekspor. Pada kegiatan jual beli di Kec. Mallusetasi hampir keseluruhan kegiatannya tidak sesuai dengan prinsip etika bisnis Islam. Hal ini dikarenakan masih banyaknya keluhan dari pihak nelayan dan kurangnya transaparansi dari pihak penadah.

\footnotetext{
${ }^{42}$ Hasil Wawancara dengan Ali (nelayan Mallusetasi), 12 Oktober 2017

${ }^{43}$ Hasil Wawancara dengan Sandi (nelayan Mallusetasi), 12 Oktober 2017

44 Hasil Wawancara dengan Ali (nelayan Mallusetasi), 12 Oktober 2017

${ }^{45}$ Hasil Wawancara dengan Lukman (nelayan Mallusetasi), 12 Oktober 2017

${ }^{46}$ Hasil Wawancara dengan Ardi (nelayan Mallusetasi), 12 Oktober 2017
} 
Al Maidah Nur, Muhammad Kamal Zubair, Mukhtar Yunus

\section{Daftar Pustaka}

Ahmad, Buchari dan Priansa, Donni Juni. 2009. Manajemen Bisnis Syariah. Bandung: Alfabeta.

Ali, Zainuddin. 2011. Metode Penelitian Hukum. Jakarta: Sinar Grafika

Alma, Buchari dan Priansa, Donni Juni. 2009. Manajemen Bisnis Syariah. Bandung: Alfabeta.

Al-Qardhawi, Yusuf. 2002. Bunga Bank. Haram, terj. Setiawan Budi Utomo. Jakarta: Akbar Media Eka Sarana.

At-Tariqi, Abdullah Abdul Husain. 2004. Ekonomi Islam Prinsip,Dasar, dan Tujuan. Yogyakarta: Magistra Insania Press, 2004.

Amalia, Fitri, "Implementasi Etika Bisnis Islam pada Pedagang di Bazar Madinah Depok" (Skripsi Sarjana: Jurusan Ekonomi Islam, Jakarta).

Azwar, Saifuddin. 2000. Metode Penelitian. Yogyakarta: Pustaka pelajar.

Badroen, Faisal. 2006. Etika Bisnis dalam Islam. Jakarta: Prenada Media Group

Bakker, Anton dan Zubair, Achmad Charris. 1989. Metodologi Penelitian Filsafat. Yogyakarta: Kanisius.

Beekum, Rafik Isa. 2004. Etika Bisnis Islami. Yogyakarta: Pustaka Pelajar.

Burhanuddin. 2011. Hukum Bisnis Syariah. Yogyakarta: UII Press Yogyakarta.

C.S.T. Kansil dan Christine S.T. Kansil,2008. Pokok-Pokok Pengetabuan Hukum Dagang Indonesia. Jakarta : Sinar Grafika.

Damanuri,Aji. 2010. Metodologi Penelitian Muamalah. Ponorogo: STAIN Po Press.

Danim, Sudarwan. 2002. Menjadi Penelitian Kualitatif: Ancangan Metodelogi, Presentasi, dan Publikasi Hasil Penelitian untuk. Mahasiswa dan Peneliti Pemula Bidang Ilmu-Ilmu Sosial, Pendidikan, dan Humaniora. Bandung: CV Pustaka Setia.

Djakfar, Muhammad. 2007. Etika Bisnis dalam Perspektif Islam. Malang: UIN-Malang Press.

Djuwaini, Dimyauddin. 2008. Pengantar Fiqh Muamalah. Yogyakarta: Pustaka Pelajar.

Ghazally, Abdul Rahman. 2010. Fiqh Muamalah,(Jakarta:Kencana Prenada Media Group.

H.B Sutopo, 2002. Pengantar Metodologi Penelitian Kualitatif. Surakarta: UNS

Press. Haroen,Nasrun. 2007. Figh Muamalah. Jakarta: Gaya Mjedia Pratama

Hasan, Ali .2009. Manajemen Bisnis Syariah. Yogyakarta:Pustaka Pelajar.

Hasan, M. Ali. 2003. Berbagai Macam Transaksi Dalam Islam (Fiqh Muamalab), .Jakarta: PT Raja Grafindo Persada.

Hidayat, Mohamad. 2010. The Sharia Economic Pengantar Ekonomi Syariah. Jakarta: Zikrul Hakim, 2010

http://id.m.wikipedia.org/wiki/Mallusetasi, Barru. (10 Maret 2017). 
Ismail. 2012. Fikih Muamalah Klasik dan Kontemporer. Bogor: Ghalia Indonesia.

Johan. 2009. Etika Bisnis Islami. Semarang: Walisongo Press.

Jusmiliani. 2008. Bisnis Berbasis Syariah. Jakarta: Bumi Aksara

Kementerian Agama RI. 1993. Al Qur'an dan Tafsimya. Semarang : CV Wicaksana.

LailiL Atifah Puspitasari, Analisis Penerapan Etika Bisnis Islam terhadap Tingkat Profitabilitas Rumah Yogurt Berdasarkan Perspektif karyawan (Studi kasus pada Rumah Yogurt di Kota Batu),skirpsi.,http://etheses.uinmalang.ac.id/1883/12/10520034_Ringkasan.pdf (10Maret 2017).

Mardalis, Metode Penelitian: Suatu Pendekatan Proposal (Cet. 7; Jakarta: Bumi Aksara, 2004), h. 26.

Mardani. 2012. Figh Ekonomi Syariah: Fiqh Muamalah. Jakarta: Kencana Prenamedia Group.

Marthon, Said Sa’ad. 2001. Ekonomi Islam di Tengah Krisis Ekonomi Global. Jakarta: Zikrul Hakim.

Muhammad danlimin, Etika \& perlindungan Konsumen Dalam Ekonomi Islam,. Yogyakarta: BPEE-Yogyakarta, 2005.

Muhammad Majdy Amiruddin, 'Khiyār (Hak Untuk Memilih) Dalam Transaksi On-Line: Studi Komparasi Antara

Lazada, Zalara Dan Blibli', Falah: Jurnal Ekonomi Syariah, 1.1 (2016), 47-62.

Mujahidin, Ahmad. 2014. Ekonomi Islam: Sejarah, Konsep, Instrumen, Negara dan Pasar, Jakarta: PT. Raja Grafindo Persada

Muslich, Ahmad Wardi. 2010. Fiqh Muamalah, Jakarta: Amzah.

Naqvi, Syed Nawab Haider.2003. Menggagas Ilmu Ekonomi Islam. Yogyakarta: Pustaka Pelajar.

Poerwadarminta, W.J.S. 2006. Kamus Umum Bahasa Indonesia. Jakarta : Balai Pustaka.

Pusat Pengkajian Hukum Islam dan Masyarakat Madani (PPHIMM), Kompilasi Hukum Ekonomi Syariah. Jakarta: Prenada Media Kencana.

Qardhawi,Yusuf. 2004. Perang Nilai dan Moral dalam Perekonomian Islam, Jakarta: Robbani Press.

Qurrata A'yunina, Tinjauan Etika Bisnis Islam Terhadap JUal Beli Buah dalam Kemasan di Terminal “Anjuk Ladang” Kabupaten Nganjuk. (Skripsi: STAIN Ponorogo, 2012).

Quthb, Sayyid. 2004. Tafsir Fi Zhilalil Qur'an Jilid 11. Jakarta : Gema Insani.

Rahman. 2002. Penjelasan lengkap Hukum-Hukum Allah (Syariab), Jakarta: Raja GrafindoPersada.

Rasjid, Sulaiman. 2014. Fiqh Islam. Bandung: Sinar Baru Algensindo.

Rivai,Veithzal dkk. 2012. Islamic Bussines And Economic Ethics mengacu pada al-Quran dan Mengikuti Jejak Rasulullah saw dalam Bisnis, Keuangan dan Ekonomi. Jakarta: PT. Bumi Aksara..

Simorangkir, O.P. 2003. Etika: Bisnis, Jabatan, dan Perbankan. Jakarta: Rineka Cipta. 
Al Maidah Nur, Muhammad Kamal Zubair, Mukhtar Yunus

Soemitro, Ronni Hanitijo. 2005. Metodelogi Penelitian Hukum,(Jakarta:Ghalia Indonesia.

Subagyo,Joko. 2004. Metode Penelitian dalam Teori dan Prektek. Jakarta: PT Rineka Cipta.

Sa'adatul Hidayah, Novita, Persaingan Bisnis Pedagang Pasar Ganefo Mranggen Demak dalam Tinjauan Etika Bisnis Islam. 2015.(Skripsi Sarjana; Jurusan Ekonomi Islam: Semarang,).

Sugiyono. 2002. Statistika Untuk Penelitian. Bandung: CV. Alfabeta.

Suhwardi dan Wajdi,Farid. 2012. Hukum Ekonomi Islam. Jakarta: Sinar Grafika.

Suwardi, Basrowi. 2008. Memahami Penelitian Kualitatif. Jakarta: Rineka Indah.

Suyanton, Bagong dan Sutinah. 2007. Metode Penelitian Sosial, (Ed.I, Cet. III; Jakarta: Kencana Prenada Media Group.

Syafe'i, Rachmat. 2006. Fiqh Muamalah. Bandung: Pustaka Setia.

Usman, Husaini \& Akbar, Purnomo Setiadi. 2008. Metodologi Penelitian Sosial. Jakarta, Bumi Aksara.

\section{Wawancara}

Wawancara dengan Tardi (nelayan Mallusetasi), 12 Oktober 2017

Wawancara dengan Saleh (penadah ikan Mallusetasi), 12 Oktober 2017

Wawancara dengan Ardi (nelayan Mallusetasi), 12 Oktober 2017

Wawancara dengan Anci (nelayan Mallusetasi), 12 Oktober 2017

Wawancara dengan Lukman (nelayan Mallusetasi), 12 Oktober 2017

Wawancara dengan Ali (nelayan Mallusetasi), 12 Oktober 2017

Wawancara dengan Sandi (nelayan Mallusetasi), 12 Oktober 2017 